\title{
Reproductive ecology of the western silvery aster Symphyotrichum sericeum in Canada
}

\author{
D. Bizecki Robson* \\ The Manitoba Museum, 190 Rupert Avenue, Winnipeg, Manitoba R3B 0N2, Canada
}

\begin{abstract}
Previous studies suggest that low seed production due to pollinator competition and seed predation may negatively affect the reproduction of the rare forb western silvery aster Symphyotrichum sericeum in Canada. Research was conducted to determine normal flower and seed production and the impact of seed predation, and to ascertain whether clipping surrounding vegetation and/or fertilizing with nitrogen stimulates flower and seed production in $S$. sericeum. Only $41 \%$ of all stems observed produced capitula, and less than $40 \%$ of the seeds in each capitulum were filled. Flower production was negatively correlated with percentage vascular plant cover and positively correlated with percentage cryptogamic cover. The main seed predator was a weevil (Anthonomus sp.) that destroyed about one-third of all capitula produced. None of the treatments applied (e.g. clipped, fertilized and clipped $\times$ fertilized) significantly increased stem height, the percentage of flowering stems or seed production over the control; clipping actually decreased stem height. Fertilizing was the only treatment that showed some promise as it increased the number of capitula per flowering stem. Flower and seed production in $S$. sericeum may be facilitated by the presence of other species that modify the microenvironment. Low flower and seed production of plants in Canada is likely due to limited soil resources and pollen, and seed predation.
\end{abstract}

KEY WORDS: Population ecology - Predation - Production - Competition · Life history traits · Conservation $\cdot$ Endangered species

\section{INTRODUCTION}

Habitat loss and fragmentation and changes in the natural disturbance regime are responsible for the endangerment of many ecosystems (Primack 2008). In Canada, one of the ecosystems most impacted by these factors is the tallgrass prairie; less than $1 \%$ remains, largely due to cultivation (Rodger 1998). The low population sizes of rare plants in endangered ecosystems make them particularly vulnerable, as reproductive difficulties such as low flower and seed production (Zimmerman \& Pyke 1988, Watson et al. 1994, Kéry et al. 2000, Fenner \& Thompson 2005) and seed predation (Evans et al. 1989, Louda et al. 1990, Hegazy \& Eesa 1991, Bevill et al. 1999, Kéry et al. 2001, Vickery 2002, Young et al. 2007) tend to occur.

Symphyotrichum sericeum (Asteraceae) is a nationally rare species in Canada (COSEWIC in press) that is found only in the tallgrass prairies of southern Manitoba and southwestern Ontario. This perennial species occurs on sandy-gravelly soils, which are being mined in some areas for use in road building and construction, resulting in habitat loss and fragmentation. One factor that negatively affects reproduction in $S$. sericeum is competitive exclusion. Competition with other co-flowering plants for pollinating insects reduces the seed set of early blooming $S$. sericeum capitula (Robson 2010). Competition with other plants for soil resources and light may also be negatively affecting flower and seed production in $S$. sericeum. Periodic disturbances, such as fire, encourage flower production in rare species of forbs that are negatively affected by competition with grasses (Watson et al. 1994, Kirkman et al. 1998, Pendergrass et al. 1999, Heather 2004). Increased flowering after a fire may be due to the nutrient flush that occurs, increase in light 
availability or a combination of these factors (Jones 1978, Gibson \& Hulbert 1987, Pendergrass et al. 1999). Mowing combined with the addition of nitrogen fertilizer has been used instead of fire to increase flowering in some rare plants (Lamont \& Runciman 1993, Heather 2004). A second factor that may be affecting $S$. sericeum is seed predation. Pre-dispersal seed predation reduces seed production in S. sericeum more than in the other species with which it shares its habitat, namely $S$. novae-angliae and $S$. ericoides var. ericoides (Newman 1999). To date, S. sericeum has not been studied sufficiently to determine the relative influence of the various factors that affect its reproduction; this lack of knowledge impedes the development of conservation plans for its recovery.

The purpose of the present study was to document the normal production of flowers and seeds in Symphyotrichum sericeum and quantify the impact of predators on seed production. As competition with grasses was hypothesized to affect the reproduction of $S$. sericeum, an experiment was conducted to determine whether applying nitrogen fertilizer and/or clipping competing vegetation to simulate a spring burn would increase flower and seed production.

\section{MATERIALS AND METHODS}

Species description. Symphyotrichum sericeum is a perennial herb that produces one to several caespitose stems from woody corm-like rootstocks that may be interconnected by short horizontal rhizomes (COSEWIC in press). The pink capitula are arranged in open, diffuse panicles. S. sericeum is a semi-obligate outbreeder pollinated by a variety of insects, including bumblebees, Halictid bees, and Syrphid and bee flies (Jones 1978, Semple et al. 1996, Robson 2010). In Manitoba, S. sericeum flowers from mid-August to midSeptember, and produces ripe cypselae, hereafter referred to as 'seeds', by early October. S. sericeum is a nationally rare species in Canada protected by the federal Species-at-Risk Act 2003, Manitoba's Endangered Species Act 1990, and Ontario's Endangered Species Act 2007. A research and collecting permit to study this plant was obtained from Manitoba Conservation. After examination, all seeds of $S$. sericeum that were harvested were released back into the park.

Study site. Birds Hill Provincial Park, located north of Winnipeg, Manitoba, Canada $\left(50^{\circ} 01^{\prime} \mathrm{N}, 96^{\circ} 53^{\prime} \mathrm{W}\right)$, is a $35 \mathrm{~km}^{2}$ protected area that contains a variety of plant communities including tallgrass prairie and oak savannah. It is one of the only areas in Canada that contains populations of Symphyotrichum sericeum. The population in the park is estimated to consist of over 4400 individuals (COSEWIC in press). Soils where $S$. sericeum occurs are sandy-gravelly, well-drained and calcareous, being derived from glaciolacustrine shoreline deposits (COSEWIC in press).

Vegetation and soils. In 2008, sixteen $2.5 \mathrm{~m}^{2}$ plots at least $5 \mathrm{~m}$ apart that contained Symphyotrichum sericeum plants were established. The number of stems, flowering stems and capitula were recorded in each plot, and densities were calculated by dividing the values by the plot area $\left(6.25 \mathrm{~m}^{2}\right)$. The absolute ground cover of all vascular plants, cryptogams, and bare ground in each plot was visually estimated using the mean percent cover for the 7 Braun-Blanquet cover classes (Mueller-Dombois \& Ellenberg 1974). To calculate the relative cover, the value of each cover type was divided by the total cover in the plot.

To determine the fertility of the soils, samples were collected to a depth of $10 \mathrm{~cm}$ from the 16 plots in the park and analyzed for $\mathrm{pH}$, electrical conductivity, and quantity of nitrogen, potassium, phosphorus and sulphur (Excova).

Seed production and predation. To assess the normal seed production and predation, 40 random Symphyotrichum sericeum plants from each of 4 subpopulations were examined in late September 2008. Plants were selected by establishing a central point in the subpopulation, then randomly choosing 20 directions (i.e. a random heading between $1^{\circ}$ and $360^{\circ}$ ) and 20 distances (i.e. random number between 1 and $25 \mathrm{~m}$ ). The flowering $S$. sericeum plants closest to the end points were examined, and the number of intact and damaged capitula on each stem were counted. Capitula that had been damaged by seed predators had blackened puncture marks on the involucres, produced very little ripe seed and had a larva or adult insect present where the seeds would normally grow. Both juvenile and adult specimens of the seed predators were collected and sent to Patrice Bouchard at Agriculture Canada, Ottawa, for identification. When the capitula were intact, they were harvested and examined in the lab.

Clipping and fertilizing experiment. One of the Symphyotrichum sericeum subpopulations with high vascular plant cover was selected as the location for this experiment, which took place in the summer of 2009. A randomized complete block design with 4 replicate blocks was used. Each block was $2.5 \mathrm{~m}^{2}$ in size and consisted of four $1 \mathrm{~m}^{2}$ plots with a $0.5 \mathrm{~m}$ buffer between them. Each plot contained 4 to 33 S. sericeum stems from which an average value was obtained. One of 4 treatments was applied to each plot: control, clipped, fertilized, or clipped $\times$ fertilized. In mid-June, the litter from half the plots was clipped and removed to simulate the effect of a spring burn. Fertilized plots received a surface application of nitrogen $\left(\mathrm{NH}_{4} \mathrm{NO}_{3}\right)$ at a rate of $10 \mathrm{~g} \mathrm{~N} \mathrm{~m}^{-2}$, the same quantity used to compare the impact of mowing and fertilizing to fire at the 
Konza Prairie Long-term Ecological Research site (Collins et al. 1998). Light levels and soil temperatures were recorded from 4 locations in all the plots once a month for 4 mo using a light meter and temperature probe, respectively. Soil samples were collected to a depth of $10 \mathrm{~cm}$ from each plot in late August and analyzed for nitrogen (Excova). S. sericeum stems were counted and measured in each plot in mid-September to determine density and height. All capitula in the plots were tallied and then harvested in early October for examination in the lab.

Seed examination. To discriminate filled from unfilled seeds, each seed was viewed under a dissecting microscope (10×) and pressed with a metal probe. Filled seeds were firm and approximately $1 \mathrm{~mm}$ thick at the widest part and unfilled seeds were soft and flat. The number of filled and unfilled seeds per capitula was counted.

Data analysis. Regression analysis was used to test the relationship between the percentage flowering stems and relative vascular plant and cryptogamic cover among the 16 study plots. ANOVA with significance of $\mathrm{p} \leq 0.05$ and least significant difference (LSD) multiple contrast analysis were used to test for differences between treatment plots with respect to stem height, percentage flowering stems, number of capitula per flowering stem, total number of seeds per stem, and soil nitrogen. Repeated measures ANOVA was used to test for differences in soil temperature and light between the treatment plots. These data were log-transformed prior to analysis due to slight skewness of the data. Statistical tests were performed using Analyze-It ${ }^{\circledR}$ (Analyze-It Software).

\section{RESULTS}

\section{Vegetation and soils}

The 16 plots contained 35 vascular plant species and at least 4 species of cryptogams, including the nitrogen-fixing blue green algae Nostoc, growing together in a biological soil crust (Table 1). Andropogon gerardii was the most abundant grass in the plots, comprising over $45 \%$ of the cover. The most abundant forbs in the plots were Solidago nemoralis followed by Symphyotrichum sericeum; together these 2 species produced $95 \%$ of all insect-pollinated flowers in the plots. Only $41 \%$ of the $S$. sericeum stems produced capitula; the average was $1.6 \pm 0.5$ capitula per flowering stem (Table 2). Regression analysis indicated that the percentage of $S$. sericeum stems that flowered was negatively correlated with the relative cover of vascular plants $\left(y=-0.6365 x+87.06, \mathrm{R}^{2}=0.3452, \mathrm{p}=0.017\right)$ and positively correlated with the relative cover of cryptogams $\left(y=-0.433 x+5.316, R^{2}=0.238, p=0.05\right)$.
Table 1. Relative cover of dominant species associated with Symphyotrichum sericeum in 16 plots located in Birds Hill Provincial Park, Manitoba, Canada. N/A: not applicable

\begin{tabular}{|lc|}
\hline Species & $\begin{array}{c}\text { \% relative cover } \\
\text { (mean } \pm \text { SE) }\end{array}$ \\
\hline Bare ground & \\
N/A & $7.07 \pm 3.4$ \\
Non-vascular species & \\
Selaginella densa & $13.1 \pm 6.6$ \\
Peltigera spp. & \\
Cladonia spp. & \\
Nostoc spp. & \\
Vascular plant species & \\
Andropogon gerardii & \\
Festuca trachyphylla & $45.3 \pm 16.5$ \\
Hesperostipa curtiseta & $8.34 \pm 8.7$ \\
Poa pratensis ssp. pratensis & $6.94 \pm 3.7$ \\
Solidago nemoralis var. longipetiolata & $4.79 \pm 0.1$ \\
Symphyotrichum sericeum & $2.43 \pm 1.7$ \\
Juniperus horizontalis & $2.18 \pm 0.1$ \\
Artemisia campestris var. borealis & $1.30 \pm 0.8$ \\
Equisetum laevigatum & $1.20 \pm 0.1$ \\
Populus tremuloides & $1.20 \pm 0.1$ \\
Symphoricarpos sp. & $1.17 \pm 1.8$ \\
Dalea purpurea var. purpurea & $0.73 \pm 0.1$ \\
Dalea candida var. candida & $0.53 \pm 0.2$ \\
Artemisia frigida & $0.45 \pm 0.3$ \\
Populus balsamifera ssp. balsamifera & $0.42 \pm 0.1$ \\
Ambrosia psilostachya var. coronopifolia & $0.42 \pm 0.1$ \\
Other species (19 taxa) & $0.42 \pm 0.1$ \\
& 2.15 \\
\hline
\end{tabular}

Table 2. Symphyotrichum sericeum. Summary of reproductive data on western silvery aster plants in Birds Hill Provincial Park, Manitoba, Canada

\begin{tabular}{|c|c|c|}
\hline Character & Mean $\pm \mathrm{SE}$ & $\begin{array}{l}\text { Sample size } \\
\text { (n) }\end{array}$ \\
\hline Stems (no. $\mathrm{m}^{-2}$ ) & $7.0 \pm 0.9$ & 100 \\
\hline Flowering stems (no. $\mathrm{m}^{-2}$ ) & $2.9 \pm 0.6$ & 100 \\
\hline Total capitula (no. $\mathrm{m}^{-2}$ ) & $4.7 \pm 0.1$ & 100 \\
\hline Capitula (no. flowering per stem) & $1.6 \pm 0.5$ & 287 \\
\hline Capitula predated $(\%)$ & $37.0 \pm 0.0$ & 256 \\
\hline Seeds (no. per capitula) & $30.4 \pm 1.7$ & 161 \\
\hline Filled seeds (\% per capitula) & $38.9 \pm 3.2$ & 161 \\
\hline Unfilled seeds ( $\%$ per capitula) & $61.1 \pm 3.2$ & 161 \\
\hline
\end{tabular}

The soil analyses indicate that the soils were slightly alkaline to neutral $(\mathrm{pH}=7.41)$ with low electrical conductivity $\left(0.16 \mathrm{dS} \mathrm{m}^{-1}\right)$. Low levels of nitrogen (1.86 ppm), phosphorus (5.44 ppm), potassium (39.33 ppm) and sulphur (3.06 ppm) indicate that these soils are highly infertile.

\section{Seed production and predation}

Of the 256 capitula examined, 37\% had been damaged by insect seed predators (Table 2). The seeds of Symphyotrichum sericeum were preyed upon by a 
species of Anthonomus weevil that lays an egg at the base of the capitulum shortly before or at bloom. The emerging larva destroys virtually every seed in the capitulum where it grows. Both larvae and adult weevils were observed cocooned in capitula. Of the undamaged capitula, the average number of seeds produced was 30 but slightly less than $40 \%$ of them were filled.

\section{Impact of clipping and fertilizing on reproduction}

Stem height was significantly lower in the clipped and clipped $\times$ fertilized plots compared to the control and fertilized plots (Table 3). None of the treatments significantly increased the percentage of flowering stems compared to the control. Plants in the fertilized plots produced significantly more capitula per flowering stem than in the other plots. Fertilized plants produced more seeds per stem than those in clipped and clipped $\times$ fertilized plots, but not more than the control plants. Light was significantly higher in the clipped plots than in the others. Nitrogen was significantly higher in the fertilized plots than in the control and clipped plots but not the clipped $\times$ fertilized plots. Soil temperature was not significantly different among the plots.

\section{DISCUSSION}

In a previous study, hand pollination was found to increase seed set in Symphyotrichum sericeum, but only by an additional 10\% (Robson 2010), suggesting that both pollen and resources are limiting. Genetic problems such as inbreeding depression are a documented cause of low seed set in some species (Ellstrand \& Elam 1993) and may be affecting $S$. sericeum; however, this was not examined in the present study. Stem and flowering stem density of $S$. sericeum was lowest at the sites with the highest vascular plant cover. I hypothesized that competition with other plants for nutrients was responsible for the low flower production observed. Evidence supporting this hypothesis is the observation that prescribed burning increases $S$. sericeum relative cover in Kansas, USA, due to an increase in light and/or nitrogen (Gibson \& Hulbert 1987). However, as prescribed burning is not always practical to conduct, an alternative strategy to stimulate flower production is desirable in some areas. Clipping and fertilizing with nitrogen had an impact comparable to fire on flower production in several rare plant species (Lamont \& Runciman 1993, Heather 2004), and for this reason was selected as a potential treatment. However, in the present study, June clipping and clipping $\times$ fertilizing did not increase flower or seed production in $S$. sericeum; in fact, a negative effect of clipping and litter removal on stem height was observed. As light was significantly higher in the clipped plots, this variable does not seem to be limiting flower production in $S$. sericeum. The presence of litter and other vascular plants may have a facilitative effect on the growth and reproduction of $S$. sericeum, possibly by increasing the organic matter content of the soil and/or decreasing water stress by providing shade and altering wind speeds (Holmgren et al. 1997). Given the high sand content of the soils where $S$. sericeum grows and the fact that adding supplemental nitrogen to clipped plots did not improve growth or seed set, moisture may be more limiting than nitrogen. Thus, mowing is not a recommended treatment in Canada as loss of co-occurring vegetation appears to hinder growth of S. sericeum; fire may have a similar negative effect.

The higher flower production of Symphyotrichum sericeum plants at sites with low vascular plant cover and high cryptogamic cover may be due to another facilitative effect between species. The cryptogamic cover at the study site consisted of both free-living and lichenized (in Peltigera spp.) Nostoc, a nitrogen-fixing blue-green algae (Brodo et al. 2001). Studies reviewed in Belnap et al. (2001) show that 5 to $88 \%$ of nitrogen fixed by Nostoc leaks into the substrate, and that plants growing in soils

Table 3. Symphyotrichum sericeum. Summary of mean values for 4 treatments in plots containing western silvery aster located in Birds Hill Provincial Park, Manitoba, Canada. Data are presented as means \pm SE. Values followed by a different letter are significantly different at the $5 \%$ confidence level (ANOVA and least significant difference [LSD] multiple contrast analysis)

\begin{tabular}{|c|c|c|c|c|}
\hline \multirow{2}{*}{ Plot value } & \multicolumn{4}{|c|}{ - Treatment } \\
\hline & Control & Fertilized & Clipped & Clipped $\times$ fertilized \\
\hline Stem height (cm) & $27.2 \pm 1.1^{\mathrm{a}}$ & $29.1 \pm 1.9^{\mathrm{a}}$ & $17.8 \pm 1.3^{\mathrm{b}}$ & $19.5 \pm 1.5^{\mathrm{b}}$ \\
\hline Flowering stems (\%) & $40.6 \pm 15.8$ & $59.0 \pm 17.7$ & $21.9 \pm 7.3$ & $28.1 \pm 8.2$ \\
\hline Capitula (no. flowering per stem) & $2.0 \pm 0.7^{\mathrm{a}}$ & $3.5 \pm 0.4^{\mathrm{b}}$ & $1.4 \pm 0.3^{\mathrm{a}}$ & $1.4 \pm 0.3^{\mathrm{a}}$ \\
\hline Seeds (no. flowering per stem) & $34.7 \pm 19.5^{\mathrm{ab}}$ & $65.9 \pm 22.9^{a}$ & $9.4 \pm 4.4^{\mathrm{b}}$ & $13.5 \pm 6.2^{\mathrm{b}}$ \\
\hline Soil nitrogen content (ppm) & $5.5 \pm 3.5^{\mathrm{a}}$ & $14.0 \pm 1.5^{\mathrm{b}}$ & $5.25 \pm 1.3^{\mathrm{a}}$ & $8.75 \pm 3.5^{\mathrm{ab}}$ \\
\hline Light (lux) & $293.3 \pm 33.8^{\mathrm{a}}$ & $260.4 \pm 30.8^{a}$ & $534.5 \pm 59.9^{b}$ & $498.7 \pm 61.9^{\mathrm{b}}$ \\
\hline Soil temperature $\left({ }^{\circ} \mathrm{C}\right)$ & $15.36 \pm 0.6$ & $15.57 \pm 0.6$ & $15.7 \pm 0.7$ & $15.4 \pm 0.7$ \\
\hline
\end{tabular}


with a cryptogamic crust possess higher concentrations of nutrients than plants not growing in crusted soils (Belnap et al. 2001). In addition to improving soil fertility, cryptogamic crusts may improve water infiltration rates, particularly on sandy soils, although this is not known conclusively (Belnap et al. 2001).

The slight increase in the number of capitula per flowering stem in the fertilized plots over the control suggests that nitrogen may be limiting reproduction in Symphyotrichum sericeum somewhat. However, fertilization did not stimulate significantly more vegetative growth or seed production over the control; there are several possible explanations for this modest response. First, the nitrogen applied may have been utilized largely by earlier growing, more competitive species, such as Andropogon gerardii. Second, the growth of $S$. sericeum, like that of many plants, may be limited by 2 or more resources simultaneously (Chapin et al. 1987, Haig \& Westoby 1988). Low availability of water, phosphorus, potassium and sulphur may have prevented the $S$. sericeum plants from fully utilizing the nitrogen added as per Liebig's Law of the Minimum (Taylor 1934). Another possible reason for the poor response is that $S$. sericeum cannot exploit an abundance of nutrients for growth and flower production due to a stresstolerant habit. Species from infertile soils are noted to absorb considerably fewer nutrients under high nutrient conditions than plants adapted to more fertile soils (Chapin 1980). S. sericeum possesses a number of traits that are characteristic of stress-tolerant plants including its production of perennial corms and rhizomes, small leaf size, slow growth and sparse litter production (Grime 2001). Stress-tolerant plants tend to be conservative, saving nutrients and energy in storage organs for use in times of scarcity rather than reproduction (Grime 2001). Although the application of fertilizer may not improve seed production in S. sericeum the year it is applied, it may improve the survival of adult plants and potential seed production in the following year (Chapin 1980).

Low population sizes combined with high seed predation is one of the reasons behind the low reproduction rates of some rare plants (Evans et al. 1989, Gisler \& Meinke 1997, Kolb et al. 2007). Seed predation is one factor affecting Symphyotrichum sericeum, as Anthonomus weevils destroyed more than one-third of all capitula that were examined. Although seed predation has been noted to vary widely from year to year in some species (Fenner \& Thompson 2005), the percentage of predated capitula observed in the present study is comparable to that in earlier reports: 30 to $34 \%$ (Newman 1999, COSEWIC in press). Fenner et al. (2002) noted that there was a positive correlation between mean capitulum size and infestation by seedeating larvae. S. sericeum suffers larger seed losses than co-flowering species with smaller capitula, namely $S$. ericoides and $S$. novae-angliae (Newman 1999). Nonetheless, predation losses in S. sericeum are not as high as in many other species; losses of 50 to $90 \%$ of all seeds are not unheard of (Fenner \& Thompson 2005).

The factors limiting seed production in Symphyotrichum sericeum are the same ones affecting other species: pollen availability limits fruit initiation, resource availability limits seed maturation and predation limits seed set (Ehrlén 1992). Applying conservation measures that affect several different aspects of reproduction would likely be more successful than measures that target only one. For example, reducing both resource competition and seed herbivory was found to increase recruitment and density by more than the sum of both single-factor effects (Louda et al. 1990, Friedli \& Bacher 2001). Hand pollination of early flowering $S$. sericeum is one potential technique to improve seed set (Robson 2010). Increasing resource availability by applying a fertilizer containing all soil macronutrients and/or water may be helpful in increasing seed set even further, although the efficacy and appropriate rates still needs to be assessed. As stress-tolerant plants perform better than competitive species when fertilizer is applied in short pulses (Grime 2001), over-fertilization should be avoided as it may encourage the growth of more competitive species, potentially negatively affecting $S$. sericeum (Grime 2001). Controlling seed predator population is another possible treatment, although one fraught with uncertainties. Pesticides have been used successfully to increase seed set in plant species affected by seed predators (Louda 1982, Ehrlén 1992, Louda \& Potvin 1995). However, the use of pesticides on $S$. sericeum may be undesirable due to potential side effects on pollinating insects. Physical barriers, such as netting, are impractical and of questionable use, as weevils were observed to chew through nylon netting to reach capitula. Prescribed burning is another possible treatment, as seed predator populations were reduced, at least temporarily, using fire in several studies (Mejeur 1998, Vickery 2002). However, Camper (2007) found that burning increased seed predation by weevils in the rare plant Sidalcea malachroides. As the wintering habits and specificity of the weevil species that predates $S$. sericeum are unknown, and as litter removal had a negative effect on plant growth, the impact of fire should be studied carefully before it is used as a management tool.

Hulme \& Benkman (2002) note that the population size of specialist seed predators is often positively correlated with the size of the crop in the preceding year, rather than the density of seeds in the current year. Thus, one of the potential consequences of applying 
treatments to increase the flower density of Symphyotrichum sericeum may be a higher predator population the following year. If conservation treatments that increase $S$. sericeum flower density are not sustained from year to year, and no measures are taken to control predator populations, the percentage of seeds predated may increase dramatically in some years, potentially offsetting the positive effect of any treatments. It may be better to focus conservation efforts on restoring $S$. sericeum to abandoned sand and gravel pits by raising plants ex situ and transplanting them, rather than attempting to alter wild seed production.

In summary, Symphyotrichum sericeum exhibits stress-tolerant characteristics that make it capable of growing in low nutrient soils. Flower and seed production in $S$. sericeum appear to be inhibited by competition with other plants for pollinators during part of the year, the presence of a weevil seed predato, and the low availability of soil resources. Both cryptogamic species and neighbouring vascular plants appear to have a facilitative effect on $S$. sericeum. Cryptogamic species may increase soil nutrients and, possibly, water availability (Belnap et al. 2001). Although other vascular plants may be competing with $S$. sericeum for some nutrients, the competition appears to be largely offset by the positive effects they have on the availability of other resources (Holmgren et al. 1997). The facilitative effect of the cryptogams is likely greater than that of the vascular plants given the higher flower production on plots with high cryptogamic cover. Additional research is needed to confirm these potential facilitative effects and determine the degree to which water and other nutrients affect growth and reproduction in $S$. sericeum, as this species appears to be limited by multiple environmental factors. To date, the only treatment known for certain to increase seed production in $S$. sericeum is hand pollination. Combining hand pollination with other treatments to address resource limitations may be even more successful.

Acknowledgements. The Manitoba Museum gratefully acknowledges the support of World Wildlife Fund-Canada, the Government of Canada and The Manitoba Museum Foundation Inc. Thanks to Manitoba Conservation staff for their assistance in study site selection, and for allowing me to conduct research in the park. Special thanks to P. Bouchard at Agriculture and Agri-Food Canada for identification of the weevil, and to E. Punter, J. Krindle and S. Robson for reviewing this document.

\section{LITERATURE CITED}

Belnap J, Kaltenecker JH, Rosentreter R, Williams J, Leonard S, Eldridge D (2001) Biological soil crusts: ecology and management. US Department of the Interior, Denver, CO
Bevill RL, Louda SM, Staniforth LM (1999) Protection from natural enemies in managing rare plants species. Conserv Biol 13:1323-1331

Brodo IM, Sharnoff SD, Sharnoff S (2001) Lichens of North America. Yale University Press, New Haven, CT

Camper TG (2007) Factors affecting pollination and seed set of a rare plant Sidalcea malachroides. MA thesis, Humboldt State University, Arcata, CA

Chapin FS III (1980) The mineral nutrition of wild plants. Annu Rev Ecol Syst 11:233-260

> Chapin FS III, Bloom AJ, Field CB, Waring RH (1987) Plant responses to multiple environmental factors. Bioscience $37: 49-57$

Collins SL, Knapp AK, Briggs JM, Blair JM, Steinauer EM (1998) Modulation of diversity by grazing and mowing in native tallgrass prairie. Science 280:745-747

COSEWIC (Committee on the Status of Endangered Wildlife in Canada) (in press) COSEWIC assessment and update status report on the western silvery aster Symphyotrichum sericeum in Canada. COSEWIC, Ottawa, ON

Ehrlén J (1992) Proximate limits to seed production in a herbaceous perennial legume, Lathyrus vernus. Ecology 73:1820-1831

Ellstrand NC, Elam DR (1993) Population genetic consequences of small population size: implications for plant conservation. Annu Rev Ecol Syst 24:217-242

> Evans EW, Smith CC, Gendron RP (1989) Timing of reproduction in a prairie legume: seasonal impacts of insects consuming flowers and seeds. Oecologia 78:220-230

Fenner M, Thompson K (2005) The ecology of seeds. Cambridge University Press, Cambridge

Fenner M, Cresswell JE, Hurley RA, Baldwin T (2002) Relationship between capitulum size and pre-dispersal seed predation by insect larvae in common Asteraceae. Oecologia 130:72-77

Friedli J, Bacher S (2001) Direct and indirect effects of a shoot-base boring weevil and plant competition on the performance of creeping thistle, Cirsium arvense. Biol Control 22:219-226

Gibson DJ, Hulbert LC (1987) Effects of fire, topography and year-to-year climatic variation on species composition in tallgrass prairie. Vegetatio 72:175-185

Gisler SD, Meinke RJ (1997) Reproductive attrition by predispersal seed predation in Sidalcea nelsoniana (Malvaceae): implications for the recovery of a threatened species. In: Kaye TN, Liston A, Love RM, Luoma DL, Meinke RJ, Wilson MV (eds) Conservation and management of native plants and fungi. Native Plant Society, Corvallis, OR

Grime JP (2001) Plant strategies, vegetation processes, and ecosystem properties. John Wiley \& Sons, New York, NY

Haig D, Westoby M (1988) On limits to seed production. Am Nat 131:757-759

Heather NA (2004) Factors controlling the fire-induced flowering response of the federally endangered Schwalbea americana L. (Scrophulariaceae). J Torrey Bot Soc 113: $16-22$

Hegazy AK, Eesa NM (1991) On the ecology, insect seed-predation, and conservation of a rare and endemic plant species: Ebenus armitagei (Leguminosae). Conserv Biol 5: 317-324

> Holmgren M, Scheffer M, Huston MA (1997) The interplay of facilitation and competition on plant communities. Ecology 78:1966-1975

Hulme PE, Benkman CW (2002) Granivory. In: Herrera CM, Pellmyr O (eds) Plant-animal interactions: an evolutionary approach. Blackwell Publishing, Malden, MA 
Jones AG (1978) Observations on reproduction and phenology in some perennial asters. Am Midl Nat 99: 184-197

Kéry M, Matthies D, Spillmann HH (2000) Reduced fecundity and offspring performance in small populations of the declining grassland plants Primula veris and Gentiana lutea. J Ecol 88:17-30

Kéry M, Matthies D, Fischer M (2001) The effect of plant population size on the interactions between the rare plant Gentiana cruciata and its specialized herbivore Maculinea rebeli. J Ecol 89:418-427

Kirkman KL, Drew MB, Edwards D (1998) Effects of experimental fire regimes on the population dynamics of Schwalbea americana L. Plant Ecol 137:115-137

Kolb A, Ehrlen J, Eriksson O (2007) Ecological and evolutionary consequences of spatial and temporal variation in predispersal seed predation. Perspect Plant Ecol Evol Syst 9: 79-100

Lamont BB, Runciman HV (1993) Fire may stimulate flowering, branching, seed production and seedling establishment in two kangaroo paws (Haemodoraceae). J Appl Ecol 30:256-264

Louda SM (1982) Distribution ecology: variation in plant recruitment over a gradient in relation to insect seed predation. Ecol Monogr 52:25-41

Louda SM, Potvin MA (1995) Effect of inflorescence-feeding insects on the demography and lifetime fitness of a native plant. Ecology 76:229-245

Louda SM, Potvin MA, Collinge SK (1990) Predispersal seed predation, postdispersal seed predation and competition in the recruitment of seedlings of a native thistle in sandhills prairie. Am Midl Nat 124:105-113

Mejeur RJ (1998). Effects of fire on the reproductive ecology of Tephrosia virginiana (L.) Pers. in the Carolina sandhills. MSc thesis, University of Georgia, Athens, GA

Mueller-Dombois D, Ellenberg H (1974) Aims and methods of vegetation ecology. John Wiley \& Sons, Toronto, ON

Editorial responsibility: Hans Juergen Boehmer, Munich, Germany
Newman K (1999) It's not easy being rare: observations and germination of Aster sericeus and two widespread congeners (A. novae-angliae and A. ericoides). BSc thesis, University of Winnipeg, Winnipeg, MB

Pendergrass KL, Miller PM, Kauffman JB, Kaye TN (1999) The role of prescribed burning in maintenance of an endangered plant species, Lomatium bradshawii. Ecol Appl 9:1420-1429

Primack RB (2008) A primer of conservation biology. Sinauer Associates, Sunderland MA

> Robson DB (2010) A comparison of flower-visiting insects to rare Symphyotrichum sericeum and common Solidago nemoralis (Asteraceae). Botany 88:241-249

Rodger L (1998) Tallgrass communities of southern Ontario: a recovery plan. World Wildlife Fund, Toronto, ON

Semple JC, Heard SB, Xiang C (1996) The asters of Ontario (Compositae: Astereae): Diplactis Raf., Oclemena E.L. Greene, Doellingeria Nees and Aster L. (including Canadanthus Nesom, Symphyotrichum Nees, and Virgulus Raf.). Univ Waterloo Biol Ser 38:1-94

Taylor WP (1934) Significance of extreme or intermittent conditions in distribution of species and management of natural resources, with a restatement of Liebig's Law of Minimum. Ecology 15:374-379

- Vickery PD (2002) Effects of the size of prescribed fire on insect predation of northern blazing star, a rare grassland perennial. Conserv Biol 16:413-421

Watson LE, Uno GE, McCarty NA, Kornkven AB (1994) Conservation biology of a rare plant species Eriocaulon kornickianum (Eriocaulaceae). Am J Bot 81:980-986

Young AS, Chang S, Sharitz RR (2007) Reproductive ecology of a federally endangered legume, Baptisia arachnifera, and its more widespread congener, B. lanceolata (Fabaceae). Am J Bot 94:228-236

Zimmerman M, Pyke GH (1988) Reproduction in Polemonium: assessing the factors limiting seed set. Am Nat 131: $723-738$

Submitted: January 26, 2010; Accepted: May 7, 2010 Proofs received from author(s): June 7, 2010 